\title{
Factors affecting English learning motivation of the economics students at Ho Chi Minh City Open University
}

\author{
Nguyen Kim Phuoc ${ }^{1 *}$, Nguyen Tran Ai Duy ${ }^{1}$ \\ ${ }^{1}$ Ho Chi Minh City Open University, Vietnam \\ *Corresponding author: phuoc.nk@ou.edu.vn
}

\begin{abstract}
ARTICLE INFO
ABSTRACT

DOI: $10.46223 / \mathrm{HCMCOUJS.}$

soci.en.8.2.282.2018

Received: October $2^{\text {nd }}, 2018$

Revised: November $26^{\text {th }}, 2018$

Accepted: December 6 $6^{\text {th }}, 2018$

Keywords:

economics students, English

Foreign Language (EFL),

HCMCOU, learning

motivation

Nowadays, foreign languages have become indispensable global integration of all nations, in general and of Vietnam, in particular. Foreign language is compulsory for Vietnamese university students and meets employers' requirements. This study aims to determine the factors which affect English Foreign Language (EFL) Learning and make recommendations for learning motivation improvement. This study was conducted to survey 434 students who are pursuing mainstream programs in the field of Business Administration, Economics, and Financial Banking at Ho Chi Minh City Open University (HCMCOU). The findings of the study show the factors related to instructors, student learning motives and training programs positively affect student motivation for learning English.
\end{abstract}

\section{Introduction}

According to the concept from EF (2017), Netherlands, Sweden and Denmark were the three countries with the best English proficiency, while Vietnam was ranked at 34/63. In Vietnam, English proficiency of students in big cities like Ho Chi Minh City and Hanoi has been considerably increased; however, English proficiency of Vietnamese students, in general, is still low.

A World Bank research indicates that low English language proficiency and lack of soft skills have put Vietnamese students at a disadvantage in job interviews. There are approximately 400 thousand graduates annually; however, nearly sixty percent of them fail to meet such requirements and the majority of the graduates cannot communicate with foreigners in English.

Realizing the importance of teaching English to university students, HCMCOU has designed EFL programs for students with a focus on providing students with substantial English proficiency, ensuring learning outcomes, satisfying employer's demands, or pursuing higher education programs in Vietnam or in developed countries. In reality, learning motivation among students is not sufficiently high; therefore, this study was conducted to determine factors that motivate students to study EFL, and hence provide scientific grounding for EFL instructors at educational institutions, especially HCMCOU, so that teaching quality, students' learning motivation and interests in English can be improved. In addition, the findings of this study can 
contribute to the high-quality human resource training process, meeting the need of internationalization of Vietnam.

At HCMCOU, there are three foreign languages for students to select: English, Chinese, Japanese and Korean. Despite this, most of the students in the field of economics choose English as it is the most widely used language.

\section{Theoretical framework}

\subsection{Theories}

Vroom (1964) defines "motivation" as a state of mind created when individuals expect to achieve the desired results or rewards if they make effort. Mitchell (1982) uses "motivation" to refer to the degree to which individual desires to reach and selects to glue his or her behavior. Robbiun (1998) regards the term as "the readiness to maximize gained results".

Some view "motivation" and "motive" as the same thing. In contrast, Alderfer (1977) finds some differences between the two terms. First, "motive" is the internal factor(s) a person wants to do something, while "motivation" is related to both the internal and external factors. In other words, "motive" is START WITH WHY, and "motivation" is BEYOND THE WHY; "motive" is Specific, and "motivation" is General. Second, "motive" requires external strength or energy, but "motivation" comes from the inside, projected by internal energy, without the need of external factors. Additionally, "motive" is short-term whilst "motivation" is long-term. Moreover, "motive" is LIKE/ WANT; in contrast, "motivation" is DESIRE.

Therefore, "motivation" is a desire and deliberate act of human beings so as to achieve desired targets or objectives with the enhanced participation of efforts. In other words, "motivation" is the "reasons that push human beings to perform acts". Signs of "motivation" include readiness, efforts, and enthusiasm for work so that organizations' and employees' aims can be reached (Alderfer, 1977). Motivation is affected by two different factors: internal, environmental and work field-related; these factors are constantly changing and hard to catch.

Maslow's hierarchy of needs (1943) shows that human behavior originates from human needs. These needs are represented in form of a five-tier pyramid, based on their importance. The need of learning belongs to the high-level group, which proves that this need does exist, and any person whose lower-tier needs are achieved or not still focuses on the need of learning as it leads them to higher-tier need levels of EFL such as esteem and self-actualization. Therefore, if we can catch their needs and qualities, we can satisfy their needs well. This means research on their need of learning leads to our success in syllabus design and implementation.

Vroom and Deci's expectancy theory (1983) implements Maslow's pyramid of needs. Expectancy theory is based on individual's cognition. It suggests the person decides an action that is done in one direction, and this action is based on another action, which depends on the "WANT/DESIRE" in that person's cognition. The urge to perform an action is decided by the desired result(s) that person wants. The core of the theory is the process of the official identifier of the dynamic feature. An individual will take an action, based on the expectation of a result or the appeal of that with the individual.

Locke's Goal-Setting theory (2002) demonstrates that specific goals and challenges lead to better performance. The doctrine also suggests that the intention to work towards the goal is the primary source of labor motivation. In order to generate labor force, it is necessary to have 
concrete and challenging goals as well as to attract laborers to set goals. The theory found that people with clear goals are more likely to succeed than those without them. The setting of goals depends on individual characteristics but focuses on five principles: clarity, challenge, commitment, feedback, and complexity. Thus, for a person with a clear learning goal, the results of the study will be good, people with clear goals, the demand for learning is also determined.

A number of authors about psyche and behavior (e.g., Murphy \& Alexander, 2000; Schunk, 2000; Stipek, 2002; \& Pintrich, 2003) have reported that motivation is an internal process that helps to push, orient and maintain continuous actions, which are required during the progress of foreign language learning. Motivation is a process in which people are pushed to perform actions to reach the desired targets and objectives. Motivation is essential to behavior. Learning motivation is comprised of two groups: social and cognitive (Tella, Ayeni, \& Popoola, 2007). Duong (2013) shows that social motivation is influenced by different elements, including learning for parents' wishes, learning for the learner's future, learning for the admiration from friends, etc. According to Tran (2010), cognitive motivation is the desire to occupy and expand knowledge, reason and method of learning, passion for learning, and appeal to learners.

\subsection{Previous studies related to the topic}

Luu (2017) bases the research on Dornyei's third foreign language learning theory (1994) to study the second language learning motive - Chinese for English language students at the University of Banking, Ho Chi Minh. The study uses a questionnaire (5-point Likert scale with 32 questions) to survey foreign language motives, Chinese, of 89 students at HCMC University of Banking. Research results show that student's learning environment has the greatest influence on students' learning motivation, followed by a range of language and ultimately learner-related factors.

Nguyen (2013) investigates "the correlation between English learning excitement and some factors influencing and predicting the level of interest of secondary school students in English" in Hanoi. The author surveyed 691 pupils from 4 schools in Hanoi and Vinh Phuc. Research shows that objective factors (families, teachers, peers and learners) (personal and attitudinal) influence the ability of students to learn English at junior high schools. In particular, personal factors, teaching methods and learning attitudes of peers are most strongly influenced.

According to Lee's study (1979), games help the instructor's lectures to be more understandable, more vivid, and clear the dullness of the lecture process, giving the classroom a lively learning environment and create the contexts in which the language of practice is useful and understandable to learners. Games help to correct errors and develop elements related to learning foreign languages such as pronunciation, language communication, collaboration and competition in learning foreign languages, giving learners the ability to review knowledge, and acquire new ideas with ease, comfort (Rixon, 1981).

Studies' Zhang (2007) and Bouzidi (2009) have shown that the learning of the English language must be based on the learner's practical needs, from the needs of using the language to perform the functions at work. Hutchinson and Water (1987) argue that specialized English teaching is based on the individual needs of learners in their own disciplines. In addition, if the focus on curriculum, teachers and learners is not adequately addressed, professional English teaching will not be effective (Luka, 2009; Savas, 2009; Widdowson, 1978). 
Myles (2016) studies second language learning (SLA): its importance to learning and teaching. The purpose of the study is to find out what factors affect learning and teaching in foreign language classes. Research results show that the results of learning foreign languages are influenced by factors such as landscape and atmosphere in the classroom, how to inspire students, how to communicate between teachers and students and it is important that students evaluate the universality (popularity) of the language.

Quan and Pham (2014) analyze factors affecting the English learning of Can Tho University's Faculty of Economics and Business Administration. The authors focus on analyzing and identifying factors that affect their need to study English. The study surveyed 160 students who were enrolled in a prepared questionnaire (5 points Likert scale). Factor groups include (i) fundamental concerns; (ii)difficulties in learning and testing; (iii) practical application; (iv) Hobbies and entertainment; (v) Study guides and learning materials and (vi) Value of the certificate. ANOVA, EFA \& CFA analyzes found three to six factors affecting students' English learning. The three influential factors were: Difficulty in learning and examination; Practical applications; Hobbies and entertainment.

Hoang and Nguyen (2016) conduct the research project "Analyzing Factors Influencing Student Motivation for Economics Students of Can Tho University". The study uses the 5 points Likert scale and uses multivariate regression, Cronbach'Alpha, and EFA analysis to determine the motivational forces of students in the Faculty of Economics at Can Tho University. The survey of 495 economics students found that the impact factors including movement, quality of trainers, training programs, learning conditions and learning environment had a positive effect on student learning motivation.

Phan and Nguyen (2011) study factors affecting the attitudes of students of Da Lat University. The purpose of the study is to determine factors affecting the learning behavior of the students of Da Lat University. The research model consists of 7 components: lecturer, teaching method, material system, syllabus, course content, practice \& practice, learning motivation, condition accommodation and living. Quantitative research (5 scores with 5 variables) conducted a survey of 812 students in the second year or others. The results show that the seven groups of factors affect students' attitudes, with motivation, curriculum and content being the three most influential factors to student attitudes. 


\section{Research model}

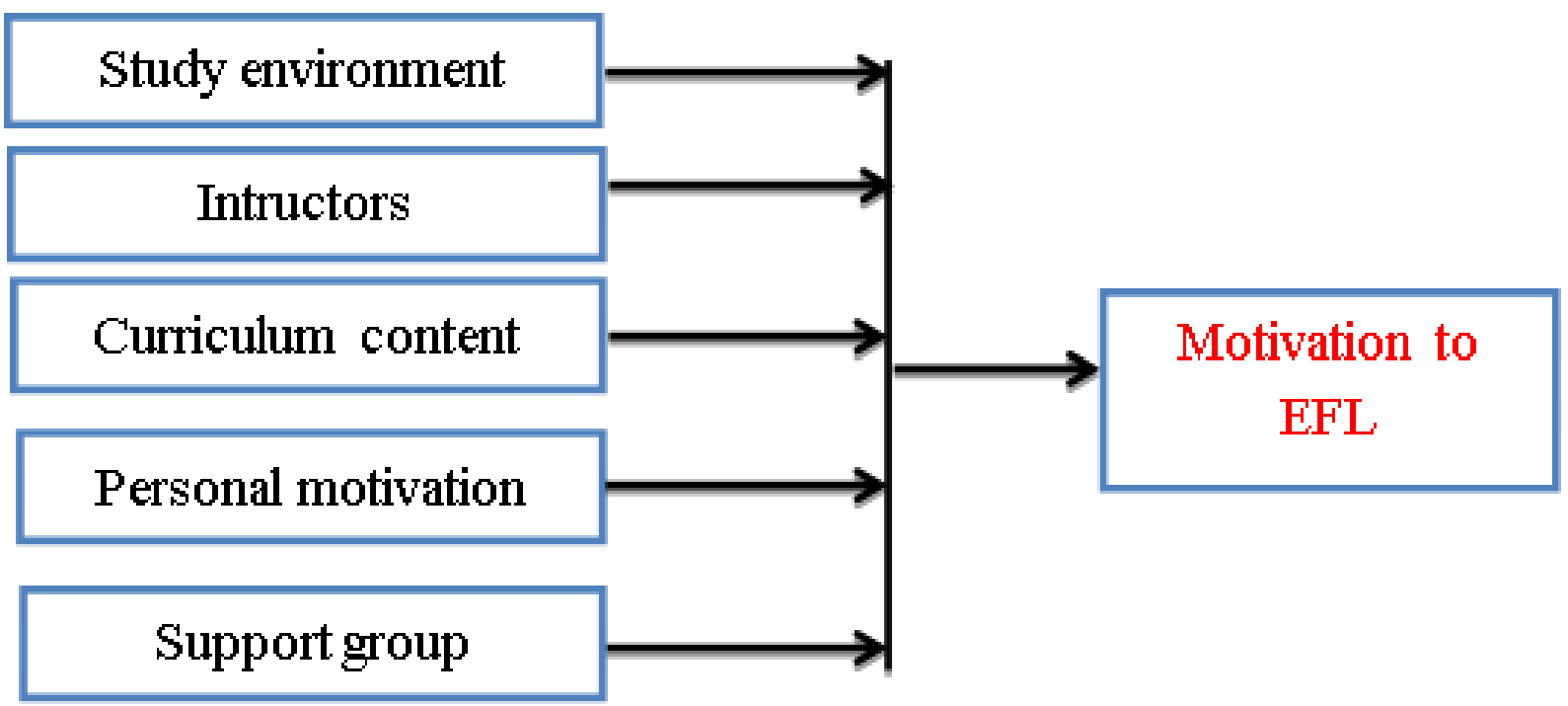

Figure 1. Recommended research model

Based on Vrom's theory of motivational theories (1964) and previous studies (e.g., Hoang \& Nguyen, 2016; Phan \& Nguyen, 2011; Murphy \& Alexander, 2000; Schunk, 2000; Stipek, 2002; \& Pintrich, 2003; Luu, 2017), recommended research model (Figure 1).

\section{Research data and the method of data analysis}

The research is done by qualitative and quantitative methods. Qualitative research was conducted by expert interviews - lecturers who have taught English for at least 10 years at Ho Chi Minh City Open University, to supplement and adjust the scales. Quantitative research uses the direct interview method for students based on questionnaires. The questionnaire was comprised of closed questions, in form of a Likert scale, interval, and nominal scale. This research used SPSS 22.0 software for data analysis. Data were mainly analyzed in terms of descriptive statistics, crossover statistics, Cronbach'Alpha and EFA scale reliability, linear regression analysis. This study used the surveys of 450 full-time students studying in Economics, Business Administration, Finance and Banking (including high-quality programs and regular programs) of Ho Chi Minh City Open University. The number of valid tickets was 450 but when putting in data for analysis, 16 voters were rejected to ensure the sample concentration (10 voters are in the fourth year of the high quality program and 6 votes are students in the fourth year of general programs). 


\section{Research results}

\subsection{Descriptive statistical analysis}

\section{Table 1}

Sample statistics by education and sex, residence status of students

\begin{tabular}{|c|c|c|c|c|c|c|}
\hline & \multicolumn{2}{|c|}{ Sex } & \multicolumn{2}{|c|}{ Residence status of students } & \multirow[b]{2}{*}{ Total } \\
\hline & & Female & Male & Other & $\begin{array}{c}\text { Permanent } \\
\text { residence in Ho Chi } \\
\text { Minh City } \\
\end{array}$ & \\
\hline \multirow[t]{3}{*}{ Majors } & Economics & 63 & 36 & 21 & 78 & 99 \\
\hline & $\begin{array}{l}\text { Business } \\
\text { administration }\end{array}$ & 93 & 25 & 40 & 78 & 118 \\
\hline & $\begin{array}{l}\text { Finance and } \\
\text { Banking }\end{array}$ & 154 & 63 & 59 & 158 & 217 \\
\hline \multicolumn{2}{|l|}{ Total } & 310 & 124 & 120 & 314 & 434 \\
\hline
\end{tabular}

Source: The researcher's data analysis

The sample size required for data analysis was 434, of which 124 male and 310 female students were enrolled in Economics, Business Administration, Finance and Banking faculty of the regular programs. In particular, most students have permanent residence in Ho Chi Minh City (314 students), and in other provinces (120 students, accounting for 27\%).

Samples were made up of 99 students studying economics. The subject of economics at HCMCOU has implemented high quality programs, and thus the 99 students in the sample are students studying regular programs. Of the 118 students who have enrolled in Business Administration, there are 46 high-quality program students, 72 regular program students. Of 154 students who have enrolled in the Finance and Banking program, there are 172 students studying in high-quality programs, 91 students studying the regular program. Samples of this study were also based on the academic years. The number of students in each academic year corresponding to fields of study is similar, ensuring the number of samples as required $(n \geq 30)$.

Table 2

Sample statistics by branch and year and curriculum program

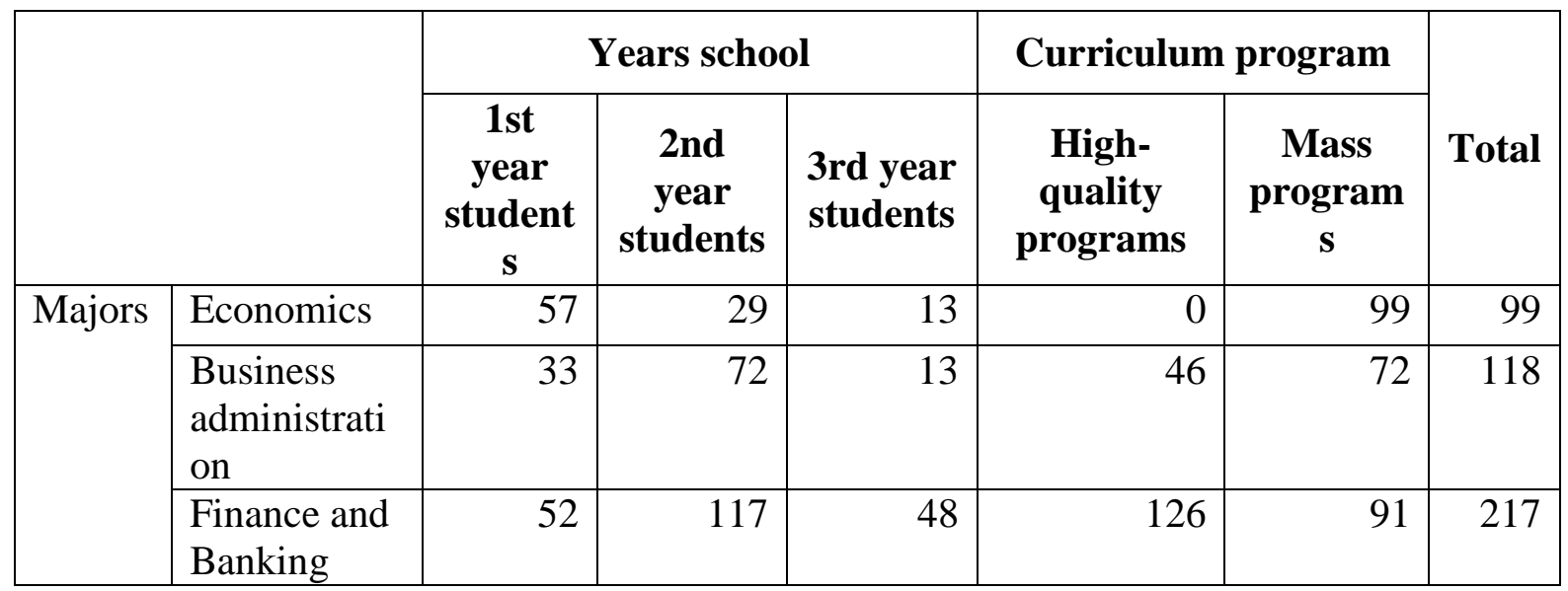




\begin{tabular}{|c|c|c|c|c|c|c|}
\hline & \multicolumn{3}{|c|}{ Years school } & \multicolumn{2}{|c|}{ Curriculum program } & \multirow[b]{2}{*}{ Total } \\
\hline & $\begin{array}{c}\text { 1st } \\
\text { year } \\
\text { student } \\
\text { s }\end{array}$ & $\begin{array}{c}\text { 2nd } \\
\text { year } \\
\text { students }\end{array}$ & $\begin{array}{l}\text { 3rd year } \\
\text { students }\end{array}$ & $\begin{array}{c}\text { High- } \\
\text { quality } \\
\text { programs }\end{array}$ & $\begin{array}{c}\text { Mass } \\
\text { program } \\
\quad \mathrm{S}\end{array}$ & \\
\hline Total & 142 & 218 & 74 & 172 & 262 & 434 \\
\hline
\end{tabular}

Source: The researcher's data analysis

Table 3

Sample time statistics

\begin{tabular}{|l|c|c|}
\hline & Numbers & Ratios $(\%)$ \\
\hline$\leq 5$ years & 34 & 7.8 \\
\hline From 6 -10 years & 277 & 63.8 \\
\hline From 11 - 15 years & 116 & 26.7 \\
\hline$\geq 15$ years & 7 & 1.6 \\
\hline & 434 & 100.0 \\
\hline
\end{tabular}

Source: The researcher's data analysis

Students who have enrolled in the school of economics have sufficient time to study English with minimum English proficiency, i.e., only $7.8 \%$ of students have been studying English for less than 5 years. The students who have English proficiency (over 6 years), most of them concentrate on the range $(11 \leq n \leq 15)$.

\section{Table 4}

Results of statistical analysis of independent variables

\begin{tabular}{|l|c|c|c|c|}
\hline & Minimum & Maximum & Mean & $\begin{array}{c}\text { Std. } \\
\text { Deviation }\end{array}$ \\
\hline Spacious study room & 1.00 & 5.00 & 3.9608 & .79014 \\
\hline Suitable teaching and learning facilities & 1.00 & 5.00 & 4.1244 & .71163 \\
\hline $\begin{array}{l}\text { Classrooms have a reasonable number of } \\
\text { students }\end{array}$ & 1.00 & 5.00 & 4.1866 & .72546 \\
\hline Atmosphere in class positive & 1.00 & 5.00 & 4.0829 & .84204 \\
\hline Nice friends relationships & 1.00 & 5.00 & 3.8963 & .84659 \\
\hline The competition needed in the classroom & 1.00 & 5.00 & 3.6774 & .85811 \\
\hline $\begin{array}{l}\text { Instructors have good professional } \\
\text { knowledge }\end{array}$ & 1.00 & 5.00 & 4.4562 & .72512 \\
\hline Instructors have easy ways to communicate & 1.00 & 5.00 & 4.5622 & .70436 \\
\hline $\begin{array}{l}\text { Instructors has a lively way of } \\
\text { communicating }\end{array}$ & 1.00 & 5.00 & 4.5323 & .68647 \\
\hline $\begin{array}{l}\text { Instructors always encourage students to } \\
\text { study }\end{array}$ & 1.00 & 5.00 & 4.4401 & .69797 \\
\hline
\end{tabular}




\begin{tabular}{|c|c|c|c|c|}
\hline & Minimum & Maximum & Mean & $\begin{array}{c}\text { Std. } \\
\text { Deviation }\end{array}$ \\
\hline $\begin{array}{l}\text { Instructors are available for expert advice } \\
\text { when students request }\end{array}$ & 1.00 & 5.00 & 4.3479 & .72638 \\
\hline $\begin{array}{l}\text { Students easily communicate with } \\
\text { instructors }\end{array}$ & 1.00 & 5.00 & 4.2811 & .78629 \\
\hline Instructors are strict instructors in teaching & 1.00 & 5.00 & 3.7719 & 1.03341 \\
\hline Instructors are fun, funny & 1.00 & 5.00 & 4.0046 & .89648 \\
\hline $\begin{array}{l}\text { Instructors feedback helps students know } \\
\text { their strengths and weaknesses in the } \\
\text { course }\end{array}$ & 1.00 & 5.00 & 4.1406 & .79610 \\
\hline $\begin{array}{l}\text { Instructors always help students set } \\
\text { deadlines to complete their learning goals }\end{array}$ & 1.00 & 5.00 & 4.0783 & .83145 \\
\hline $\begin{array}{l}\text { Instructors respect the student's personal } \\
\text { expression choice }\end{array}$ & 1.00 & 5.00 & 4.1498 & .80596 \\
\hline $\begin{array}{l}\text { The training program has a reasonable } \\
\text { capacity }\end{array}$ & 1.00 & 5.00 & 4.2581 & .74309 \\
\hline $\begin{array}{l}\text { The curriculum meets the requirements of } \\
\text { future career development of students. }\end{array}$ & 1.00 & 5.00 & 4.2419 & .75619 \\
\hline $\begin{array}{l}\text { Number of hours (time) taught by the } \\
\text { training program is reasonable }\end{array}$ & 1.00 & 5.00 & 4.1590 & .77494 \\
\hline $\begin{array}{l}\text { The books and learning materials are } \\
\text { adequate and appropriate }\end{array}$ & 1.00 & 5.00 & 4.0991 & .83892 \\
\hline $\begin{array}{l}\text { The enthusiastic support of Faculty and } \\
\text { subject when students needed }\end{array}$ & 1.00 & 5.00 & 3.8963 & .81603 \\
\hline Fairness and seriousness in examinations & 1.00 & 5.00 & 4.0737 & .82350 \\
\hline $\begin{array}{l}\text { The library has a full source of reference } \\
\text { material }\end{array}$ & 100 & 5.00 & 4.1382 & .78629 \\
\hline $\begin{array}{l}\text { Online applications for learning has a full } \\
\text { source }\end{array}$ & 1.00 & 5.00 & 4.1336 & .76022 \\
\hline This subject is for compulsory study & 1.00 & 5.00 & 3.3272 & 1.10796 \\
\hline $\begin{array}{l}\text { You learn English because it is needed for } \\
\text { your study and your life now }\end{array}$ & 1.00 & 5.00 & 4.2627 & .80995 \\
\hline $\begin{array}{l}\text { You learn English as a necessity for your } \\
\text { study and life later }\end{array}$ & 1.00 & 5.00 & 4.4055 & .74236 \\
\hline $\begin{array}{l}\text { English is a foreign language that your } \\
\text { parents do not encourage learning }\end{array}$ & 1.00 & 5.00 & 3.4355 & 1.19535 \\
\hline $\begin{array}{l}\text { English is a language that helps you } \\
\text { discover the values of other cultures in the } \\
\text { world }\end{array}$ & 1.00 & 5.00 & 3.8410 & .97785 \\
\hline $\begin{array}{l}\text { Studying English makes you feel like you } \\
\text { can actively participate in activities that } \\
\text { take place overseas }\end{array}$ & 1.00 & 5.00 & 4.0945 & .79130 \\
\hline $\begin{array}{l}\text { Students learn English because students } \\
\text { love English culture }\end{array}$ & 1.00 & 5.00 & 3.7719 & .92241 \\
\hline
\end{tabular}




\begin{tabular}{|l|c|c|c|c|}
\hline & Minimum & Maximum & Mean & $\begin{array}{c}\text { Std. } \\
\text { Deviation }\end{array}$ \\
\hline $\begin{array}{l}\text { You learn because you feel confident that } \\
\text { you learn }\end{array}$ & 1.00 & 5.00 & 3.7604 & .94304 \\
\hline $\begin{array}{l}\text { You learn to prove you have a good } \\
\text { education }\end{array}$ & 1.00 & 5.00 & 3.5806 & .99151 \\
\hline $\begin{array}{l}\text { Students learn English because of social } \\
\text { recognition }\end{array}$ & 1.00 & 5.00 & 3.5968 & .97833 \\
\hline $\begin{array}{l}\text { Students learn English becaouse it is taught } \\
\text { in high school }\end{array}$ & 1.00 & 5.00 & 3.5000 & .97130 \\
\hline $\begin{array}{l}\text { Motivation in EFL is decided most by } \\
\text { Personal motivation }\end{array}$ & 1.00 & 5.00 & 4.1267 & .71285 \\
\hline $\begin{array}{l}\text { Motivation in EFL is decided most by } \\
\text { instructor }\end{array}$ & 1.00 & 5.00 & 3.9493 & .81113 \\
\hline $\begin{array}{l}\text { Motivation in EFL is decided most by } \\
\text { curriculum content }\end{array}$ & 1.00 & 5.00 & 3.9332 & .83384 \\
\hline $\begin{array}{l}\text { Motivation in EFL is decided most by } \\
\text { study environment }\end{array}$ & 1.00 & 5.00 & 4.0023 & .81413 \\
\hline
\end{tabular}

Source: The researcher's data analysis

The study uses the Likert scale of 5 (1: Very unimportant, 2: not important, 3: average, 4: important and 5: very important). Thus, most variables have a minimum value of 1 and a maximum of 5. The majority of opinions are similar in respect of ratings, except: "Instructors are strict instructors in teaching", "English is a foreign language that your parents do not encourage learning" and "This subject is for compulsory study" are three factors with high standard deviation variables (Std Deviation $\geq 1$ ), which means that students are different in recognizing the importance of these three variables. All 41 variables have an average value of over 3 (mean $\geq 3.00$ ) indicating that the students studied the direction of factors from important to very important.

\section{Table 5}

Summary of Cronbach's Alpha analyzes

\begin{tabular}{|c|l|c|c|c|c|}
\hline $\begin{array}{c}\text { Numerical } \\
\text { order }\end{array}$ & \multicolumn{1}{|c|}{ Scales } & $\begin{array}{c}\text { N of } \\
\text { Items }\end{array}$ & $\begin{array}{c}\text { Corrected } \\
\text { Item-Total } \\
\text { Correlation } \\
\text { (Minimum) }\end{array}$ & $\begin{array}{c}\text { Corrected } \\
\text { Ittem-Total } \\
\text { Correlation } \\
\text { (Maximum) }\end{array}$ & $\begin{array}{c}\text { Cronbach's } \\
\text { Alpha }\end{array}$ \\
\hline 1 & Study environment & 6 & 0.416 & 0.698 & 0.829 \\
\hline 2 & Instructor & 11 & 0.374 & 0.716 & 0.886 \\
\hline 3 & Curriculum content & 4 & 0.578 & 0.681 & 0.801 \\
\hline 4 & Support group & 4 & 0.606 & 0.678 & 0.815 \\
\hline 5 & Personal motivation & 11 & 0.310 & 0.659 & 0.811 \\
\hline 6 & $\begin{array}{l}\text { Motivation in EFL } \\
\text { (Dependent variables) }\end{array}$ & 5 & 0.426 & 0.668 & 0.785 \\
\hline & Total & 41 & & & \\
\hline
\end{tabular}

Source: The researcher's data analysis 
Cronbach's Alpha analysis of all variables belonging to the independent and dependent variables was Cronbach's Alpha $\geq 0.8$ and Corrected Item-Total Correlation $\geq 0.3$. Therefore, the scales in the model are reliable and qualified to conduct exploratory factor analysis (EFA).

All 36 independent variables were included in the EFA analysis. The analysis results showed that $\mathrm{KMO}=0.903$, Sig. $=0.000<0.05$, initial Eigenvalues $=68.642$ with 9 element groups. However, there are many variables with factor load less than 0.5 . These variables $(20$ variables) have a factor load less than 0.5 , which is eliminated. Research conducted eliminated these variables and performed EFA analysis again. Results of the final EFA analysis showed that $\mathrm{KMO}=0.847$; Bartlett's Test with Sig. $=0.000$; Total Variance Explained $=68.303$; Eigenvalues $=0.973$, all variables have a satisfactory loading factor $(\geq 0.5)$.

\section{Table 6}

Results of EFA analysis of final independent variables

\begin{tabular}{|c|c|c|c|c|}
\hline & \multicolumn{4}{|c|}{ Component } \\
\hline & 1 & 2 & 3 & 4 \\
\hline Instructors have a lively way of communicating & .583 & & & \\
\hline Instructors have easy ways to communicate & .592 & & & \\
\hline $\begin{array}{l}\text { Instructors are available for expert advice when students } \\
\text { request }\end{array}$ & .595 & & & \\
\hline Instructors always encourage students to study & .572 & & & \\
\hline Students easily communicate with instructors & .595 & & & \\
\hline Instructors have good professional knowledge & .518 & & & \\
\hline $\begin{array}{l}\text { Students learn English as a means of demonstrating good } \\
\text { education }\end{array}$ & & .861 & & \\
\hline $\begin{array}{l}\text { Students learn English because they feel confident that they } \\
\text { learn }\end{array}$ & & .777 & & \\
\hline Students learn English because of social recognition & & .782 & & \\
\hline Students learn English because students love English culture & & .704 & & \\
\hline Students learn English because it is taught in high school & & .666 & & \\
\hline The books and learning materials are adequate and appropriate & & & .717 & \\
\hline $\begin{array}{l}\text { Number of hours (time) taught by the training program is } \\
\text { reasonable }\end{array}$ & & & .599 & \\
\hline $\begin{array}{l}\text { The curriculum meets the requirements of future career } \\
\text { development of students. }\end{array}$ & & & .556 & \\
\hline $\begin{array}{l}\text { English is a foreign language that your parents do not } \\
\text { encourage learning }\end{array}$ & & & & 1.011 \\
\hline This subject is for compulsory study & & & & .893 \\
\hline \multicolumn{5}{|c|}{$\begin{array}{l}\text { Extraction Method: Principal Component Analysis; Rotation Method: Varimax with Kaiser } \\
\text { Normalization. }\end{array}$} \\
\hline \multicolumn{5}{|c|}{$\begin{array}{l}\text { KMO }=0.847 ; \text { Bartlett's Test }{ }^{\mathrm{a}} \text { with Sig. }=0.000 ; \text { Total Variance Explained }=68.303 ; \\
\text { Eigenvalues }=0.973\end{array}$} \\
\hline
\end{tabular}

Source: Data analysis result of the research 
Analysis of EFAs for the dependent variables - dynamics of English amateurs.

Analysis results show that the coefficient of KMO, Bartlett's Test with Sig, Total Variance Explained and Eigenvalues are all satisfactory. However, the "English dynamics determined by individual motivation" is eliminated because factor loading $(0.150 \leq 0.3)$ is not available. After eliminating this variable, the remaining variables were included in the second EFA analysis. The results showed that the coefficient $\mathrm{KMO}=0.715$; Bartlett's Test with Sig. $=0.000$; Total Variance Explained $=60.873$; Eigenvalues $=1.719$. Thus, from the first 5 observed variables, after the EFA analysis, the dependent variable group had only four observed variables.

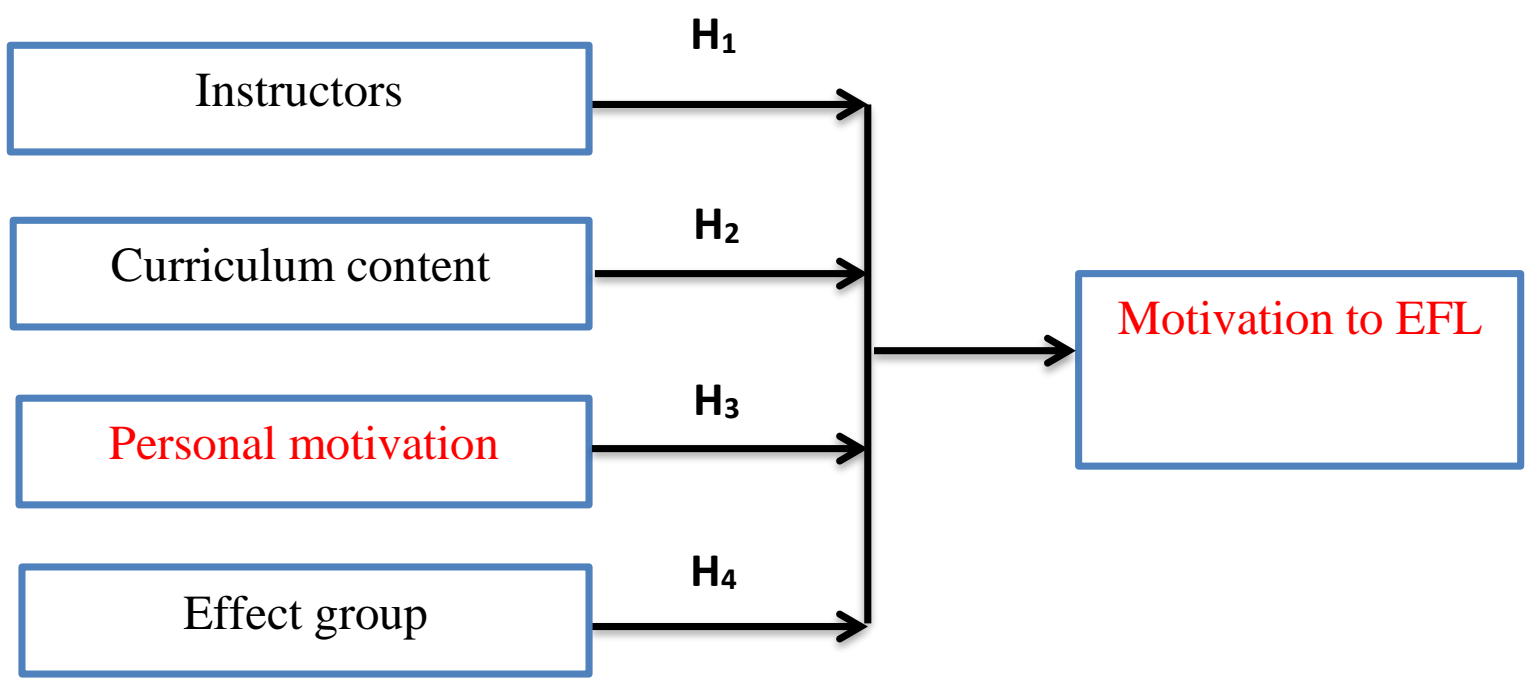

Figure 2. Adjustment model (after analysis EFA)

\subsection{Test correlation matrix and multicollinearity}

According to Table 11, the four factors included in the analysis and regression testing conditions had the "impact group" factor knocked out because Sig is greater than 0.05. The remaining groups F1, F2, F3 were significantly correlated with "Motivation to EFL" with 99\% reliability.

In Table 7 , the adjusted $\mathrm{R}^{2}$ of 0.288 means that $28.8 \%$ of students' "Motivation to EFL" change is explained by faculty-related factors, program content, and motivational factors. Thus, the statistically significant assurance model with the tests was conducted; there was a close relationship between the variables independent of the dependent variable.

Table 7

Model test results and hypotheses

\begin{tabular}{|l|l|c|c|c|c|}
\hline Hypotheses & Expected & $\begin{array}{c}\text { Record the } \\
\text { regression } \\
\text { result }\end{array}$ & $\begin{array}{c}\text { Standardized } \\
\text { regression } \\
\text { coefficient }\end{array}$ & P & $\begin{array}{c}\text { Test } \\
\text { results }\end{array}$ \\
\hline $\mathrm{H}_{1} \rightarrow$ Motivation to EFL & Positive & Positive & $0.228^{* * *}$ & 0.000 & Accept \\
\hline $\mathrm{H}_{2} \rightarrow$ Motivation to EFL & Positive & Positive & $0.226 * * *$ & 0.000 & Accept \\
\hline $\mathrm{H}_{3} \rightarrow$ Motivation to EFL & Positive & Positive & $0.300^{* * *}$ & 0.000 & Accept \\
\hline
\end{tabular}




\begin{tabular}{|l|l|c|c|c|r|}
\hline \multicolumn{1}{|c|}{ Hypotheses } & Expected & $\begin{array}{c}\text { Record the } \\
\text { regression } \\
\text { result }\end{array}$ & $\begin{array}{c}\text { Standardized } \\
\text { regression } \\
\text { coefficient }\end{array}$ & P & \multicolumn{1}{|c|}{$\begin{array}{c}\text { Test } \\
\text { results }\end{array}$} \\
\hline $\mathrm{H}_{4} \rightarrow$ Motivation to EFL & Positive & Positive & 0.022 & 0.614 & Reject \\
\hline Test results & & & 0.299 \\
\hline & $\mathrm{R}^{2}$ & & 0.288 \\
\hline & $\mathrm{R}^{2}$ square & $26.009(0.000)$ \\
\hline
\end{tabular}

Source: The researcher's data analysis

With Prob $($ F-statistic $)=0,000$, Durbin-Watson $=1.673$ and F=26.009 (Table 7), it can be specified that the given model matching with the data (99\%). Table 7 for the current modifier found has an invalid parsing ANOVA with the trustily $100 \%$ ( $\mathrm{Sig}=0,00$ ); enough condition may be matching model built to fit with file data. Finally, the Independent Samples Test and an in-depth analysis of ANOVA were used to examine differences in English language dynamics among different criteria.

\section{Table 8}

ANOVA (between groups)

\begin{tabular}{|c|c|c|c|c|c|c|}
\hline & & $\begin{array}{l}\text { Sum of } \\
\text { Squares }\end{array}$ & df & $\begin{array}{c}\text { Mean } \\
\text { Square }\end{array}$ & $\mathbf{F}$ & Sig. \\
\hline \multirow{3}{*}{ Majors } & $\begin{array}{l}\text { Between } \\
\text { Groups }\end{array}$ & 62.277 & 97 & \multirow[t]{3}{*}{.642} & \multirow[t]{3}{*}{.973} & \multirow[t]{3}{*}{.554} \\
\hline & Within Groups & 221.640 & 336 & & & \\
\hline & Total & 283.917 & 433 & & & \\
\hline \multirow{3}{*}{ Sex } & $\begin{array}{l}\text { Between } \\
\text { Groups }\end{array}$ & 22.961 & 97 & \multirow[t]{3}{*}{.237} & \multirow[t]{3}{*}{1.212} & \multirow[t]{3}{*}{.100} \\
\hline & Within Groups & 65.611 & 336 & & & \\
\hline & Total & 88.571 & 433 & & & \\
\hline \multirow{3}{*}{ Years } & $\begin{array}{l}\text { Between } \\
\text { Groups }\end{array}$ & 39.656 & 97 & \multirow[t]{3}{*}{.409} & \multirow[t]{3}{*}{.829} & \multirow[t]{3}{*}{.864} \\
\hline & Within Groups & 165.689 & 336 & & & \\
\hline & Total & 205.346 & 433 & & & \\
\hline \multirow{3}{*}{ Learning program } & $\begin{array}{l}\text { Between } \\
\text { Groups }\end{array}$ & 28.360 & 97 & \multirow[t]{3}{*}{.292} & \multirow[t]{3}{*}{1.302} & \multirow[t]{3}{*}{.046} \\
\hline & Within Groups & 75.475 & 336 & & & \\
\hline & Total & 103.834 & 433 & & & \\
\hline
\end{tabular}

Source: The researcher's data analysis

According to Anova's analysis, there is a difference in student's "Motivation in EFL" between the general programs and the program of high quality (Sig. $\leq 0.1)$ dynamics of English by subject and by year (Table 9). 
Table 9

ANOVA

\begin{tabular}{|c|c|c|c|c|c|}
\hline & $\begin{array}{c}\text { Sum of } \\
\text { Squares }\end{array}$ & Mean Square & & $\mathbf{N}$ & Mean \\
\hline Between Groups & 1.421 & 1.421 & $\begin{array}{l}\text { program of high } \\
\text { quality }\end{array}$ & 172 & .0706098 \\
\hline Within Groups & 431.579 & .999 & general programs & 262 & -.0463545 \\
\hline Total & 433.000 & & Total & 434 & $0 \mathrm{E}-7$ \\
\hline \multicolumn{3}{|c|}{$\begin{array}{l}\text { Levene Statistic (Test of Homogeneity of Variances) } \\
=.007\end{array}$} & & \multicolumn{2}{|c|}{ Sig. $($ Anova $)=.034$} \\
\hline
\end{tabular}

Source: The researcher's data analysis

Table 10

Levene's Test for Equality of Variances

\begin{tabular}{|c|c|c|c|c|c|c|}
\hline & \multicolumn{2}{|c|}{$\begin{array}{c}\text { Levene's Test for } \\
\text { Equality of } \\
\text { Variances } \\
\end{array}$} & \multicolumn{3}{|c|}{ Independent Samples Test } \\
\hline & & $\mathbf{F}$ & Sig. & Sex & $\mathbf{N}$ & Mean \\
\hline \multirow{2}{*}{$\begin{array}{l}\text { Motivation in } \\
\text { EFL }\end{array}$} & \begin{tabular}{|l} 
Equal \\
variances \\
assumed \\
\end{tabular} & 3.626 & .058 & male & 124 & -.0187510 \\
\hline & $\begin{array}{l}\text { Equal } \\
\text { variances not } \\
\text { assumed }\end{array}$ & & & female & 310 & .0075004 \\
\hline
\end{tabular}

Source: The researcher's data analysis

Test of Homogeneity of Variances (Table 9) shows that High Quality English learner programs are better than general programs. This is a good point because the standard English output of high quality programs requires more, which motivates students to learn better. Levene's Test for Equality of Variances (Table 10) The English language dynamics of female students are better than that of male students.

\subsection{Regression analysis results}

Table 11

Coefficients $^{\mathrm{a}}$ - Regression results

\begin{tabular}{|l|c|c|c|c|c|c|c|}
\hline & \multicolumn{2}{|c|}{$\begin{array}{c}\text { Unstandardized } \\
\text { Coefficients }\end{array}$} & $\begin{array}{c}\text { Standardized } \\
\text { Coefficients }\end{array}$ & \multirow{2}{*}{ t } & \multicolumn{2}{|c|}{ Sig. } & \multicolumn{2}{|c|}{$\begin{array}{c}\text { Collinearity } \\
\text { Statistics }\end{array}$} \\
\cline { 2 - 8 } & B & $\begin{array}{c}\text { Std. } \\
\text { Error }\end{array}$ & Beta & & & Tolerance & VIF \\
\cline { 2 - 8 } (Constant) & .000 & .044 & & -.003 & .998 & & \\
\hline Instructors & .229 & .044 & .228 & 5.263 & .000 & .999 & 1.001 \\
\hline
\end{tabular}




\begin{tabular}{|l|c|c|c|c|c|c|c|}
\hline & \multicolumn{2}{|c|}{$\begin{array}{c}\text { Unstandardized } \\
\text { Coefficients }\end{array}$} & $\begin{array}{c}\text { Standardized } \\
\text { Coefficients }\end{array}$ & \multirow{2}{*}{$\mathbf{t}$} & \multicolumn{2}{|c|}{ Sig. } & \multicolumn{2}{|c|}{$\begin{array}{c}\text { Collinearity } \\
\text { Statistics }\end{array}$} \\
\cline { 2 - 8 } & $\mathbf{B}$ & $\begin{array}{c}\text { Std. } \\
\text { Error }\end{array}$ & Beta & & & Tolerance & VIF \\
\cline { 2 - 8 } $\begin{array}{l}\text { Personal } \\
\text { motivation }\end{array}$ & .226 & .043 & .226 & 5.209 & .000 & 1.000 & 1.000 \\
\hline $\begin{array}{l}\text { "curriculum } \\
\text { content" }\end{array}$ & .301 & .043 & .300 & 6.926 & .000 & .999 & 1.001 \\
\hline Effect groups & .022 & .044 & .022 & .505 & .614 & .999 & 1.001 \\
\hline
\end{tabular}

a. Dependent Variable: Motivation in EFL

Source: The researcher's data analysis

Factor "Instructors" has coefficients B $=0.229$ (positive sign) and Sig. $=0.000$. This result shows Factor "Instructors" has a positive impact on "Motivation in EFL" of student. The results also coincide findings with Myles's (2016) Hoang and Nguyen (2016), Phan and Nguyen (2011). The results are also perfectly consistent with the fact that the "teacher" is one of the objective factors that have a significant direct impact on the behavior, attitude and learning outcomes of students.

Factor "Personal motivation" has coefficients B $=0.226$ (positive sign) and Sig. $=0.000$. This result shows Factor "Personal motivation" has a positive impact on students' "English dynamics". The results also coincide with the findings of Zhang (2007), Bouzidi (2009), Nguyen (2013), and Hoang and Nguyen (2016). The results are well suited to reality because "personal motivation" determines behavior, attitudes, and learning outcomes. A student with positive learning motivation will try to meet the needs and goals that he or she wishes to achieve.

Factor "curriculum content" has coefficients $\mathrm{B}=0.301$ (positive sign) và Sig. $=0.000$. This result shows, factor "curriculum content" has a positive impact on students' "Motivation in EFL". This is the group with the highest regression coefficient, which means that the strongest among the three groups has a positive effect on the dependent variable. This result also coincides with the results from the studies of Myles (2016), Hoang and Nguyen (2016), Phan and Nguyen (2011). The results also perfectly match the fact that the contents of the teaching and learning programs have an impact on student learning, creating passion, excitement for students, and especially when they learn foreign languages. Attractive study programs will create more motivation for students.

\section{Conclusion and recommendations}

\subsection{Conclusion}

The initial research model consists of five groups of factors (with 36 independent variables) that affect the motivation in EFL, dynamics of elementary students in HCMCOU. The scale reliability test results show that the scale of measurement used to ensure the reliability of the evidence is that no observable variable is eliminated. Discovery Factor Analysis (EFA) shows, $\mathrm{KMO}=0.847$; Bartlett's Test ${ }^{\mathrm{a}}$ with Sig. $=0.000$; Total Variance Explained = 68.303; Eigenvalues $=0.973$. Thus, the scale used in the study is consistent, ensuring reliability. The 
results of linear regression analysis show that there are three groups of factors: Lecturer, individual motivation and program content. These have a positive impact on the dependent variable, in which the program content has the strongest impact, followed by personal motives and trainers. A set of factors such as parents and program imperatives have not found signs of impact on students "Motivation in EFL".

\subsection{Recommendations}

First, schools and faculties need to research and refine the non-specialized English language training program for students to meet the future career development requirements of students. Also, they need to study to adjust the length of instruction according to the program more reasonable and focus on providing adequate teaching materials as the student-oriented materials for internationalization. At the same time, it is possible to integrate online teaching with learning programs so that students can learn more about English and foreign languages in general.

Second, lecturers, in addition to improving their level and teaching skills, also research other skills such as good communication skills, and research methods of communication so that students will be motivated to learn English. In particular, faculty members need to develop positive approaches to motivate students to learn. In order to do this, other members in faculty have to grasp the requirements and aspirations of students through their interactions with students. Students are often afraid to learn foreign languages, especially speaking, so teachers must create a suitable "communication" environment in order to fully exploit students' potential and strengths.

Third, according to survey results as well as reality, students choose English as a foreign language (non-English major) because English was selected during their high school years. However, there are hidden factors in the student's motivation that can help them learn better, such as confidence, interest in learning. The reason is that they want to prove themselves, like studying culture and especially want to be "socially recognized as classy". Teachers must understand the learners and learner needs so as to stimulate the motivation of learning and help them realize the motivating factors such as beliefs, passions, recognition, etc.

\section{References}

Alderfer, C. P. (1977). A critique of Salancik and Pfeffer's examination of need-satisfaction theories. Administrative Science Quarterly, 22, 658-669.

Bouzidi, H. (2009). Between the ESP classroom and the workplace: Bridging the gap. English Teaching Forum, 47(3), 10-19.

Dan Tri. (2017). English proficiency is low, information from the EF. EPI Global English Language Proficiency Report dated 01/12/2017.

Hoang, T. M. N., \& Nguyen, T. K. (2016). Analysis of factors affecting the motivation of studying economics of Can Tho University. Scientific Magazine of Can Tho University, $46,107-115$. 
Hutchinson, T., \& Water, A. (1987). English for specific purposes: A learning centred approach. Cambridge, UK: CUP.

Lee, W. R. (1979). Language teaching games and contexts. Oxford, UK: Oxford University Press.

Locke, J. (2002). The law of nature: In political writings. In G. Mark (Ed.), The history of political thought. Cambridge, UK: CUP.

Luka, I. (2009). Development of students' English for specific purposes. Competence in tourism studies at tertiary level. English for Specific Purposes World, 8(4), 1-32.

Mitchell, T. R. (1982). Motivation: New directions for theory, research, and practice. The Academy of Management Review, 7(1), 80-88.

Myles, F. (2016). Second language acquisition (SLA) research: Its significance for learning and teaching issues. Retrieved September 25, 2018, from https://www.llas.ac.uk/resources/gpg/421

Nguyen, X. L. (2013). The relationship between the motivation of learning English with some influencing factors and predicting the level of interest in learning English among junior high school students. VNU Journal Science, Foreign Study, 29(1), 26-32.

Phan, H. T., \& Nguyen, T. Q. L. (2011). Factors influencing the learning attitudes of students of Da Lat University. Journal of Science and Technology Development, 14(2), 2011.

Quan, M. N., \& Pham, P. V. (2014), Factor analysis affecting English learning of Can Tho University faculty of economics and business administration. Cantho University Science Journal - Part C: Social Sciences, Humanities and Social Sciences, 30(2014), 89-95.

Rixon, S. (1981). How to use games in language teaching (Essential language teaching series). London, UK: Macmillan Education.

Robbiun, G. (1998). Impact of motivation on employees performance. Journal of Socia Sciences, 4(2), 22-31.

Rollinson et al. (1998). (2nd Eds.) Motivation and Leadership, a wider perspective, 12-22. Basingstoke, UK: Macmillan Publishers limited.

Savas, B. (2009). Role of functional academic literacy in ESP teaching: ESP teacher training in Turkey for sustainable development. The Journal of International Social Research, 2(9), 395-406.

Tella, A., Ayeni, C. O., \& Popoola, S. O. (2007). Work motivation, job satisfaction, and organisational commitment of library personnel in academic and research libraries in Oyo state, Nigeria. Library Philosophy and Practice, 9(2).

Vroom, V. H. (1964). Work and motivation. New York, NY: Wiley.

Vroom, V. H., \& Deci, E. L. (1983). Management and motivation: Selected readings. London, UK: Penguin.

Widdowson, H. G. (1978). Teaching language as communication. London, UK: OUP. 
Widdowson, H. G. (1981). English for specific purposes: Criteria for course design in English for academic and technological purposes. In L. Selinker, E. Tarone \& V. Hanzeli (Eds.). Rowley, MA: Newburry.

Zhang, Z. (2007). Towards an integrated approach to teaching business English: A Chinese experience. English for Specific Purposes, 26(4), 399-410. 